\title{
Uncommon type of wound: Morel-Lavallée lesion
}

\author{
Mesut Mutluoglu (10 , Jonas De Melio, Thomas Debrouwere, Emanuel Laridon
}

Department of Radiology, AZ Delta Campus Rumbeke, Roeselare, Belgium

Correspondence to Dr Mesut Mutluoglu; mesut.mutluoglu@azdelta.be

Accepted 27 March 2021

\section{DESCRIPTION}

A 26-year-old goalkeeper presented with pain and swelling of the left trochanteric region 2 weeks after he fell over it. On physical examination, he had a large round-shaped swelling over the left trochanter majus. There were no signs of infection or open wound and the patient was otherwise normal. An ultrasound scan (US) revealed a sharply defined elongated fluid collection/haematoma overlying the left trochanter majus between the subcutaneous adipose tissue and the underlying fascia, measuring approximately $7 \times 0.7 \times 5 \mathrm{~cm}$ in diameter suggestive of a Morel-Lavallée lesion (MLL) (figure 1A,B). The lesion demonstrated no flow on colour Doppler and no other pathological findings regarding the deeper musculature were noted.

MLL was first described by the French surgeon Victor-Auguste-François Morel-Lavallee in 1863. It is a relatively rare condition that usually develops following traumatic injury. This is a closed degloving injury that occurs as a result of pressure and shear stress between the subcutaneous tissue and the superficial fascia which are separated from each other while disrupting the surrounding vasculature and lymphatic vessels

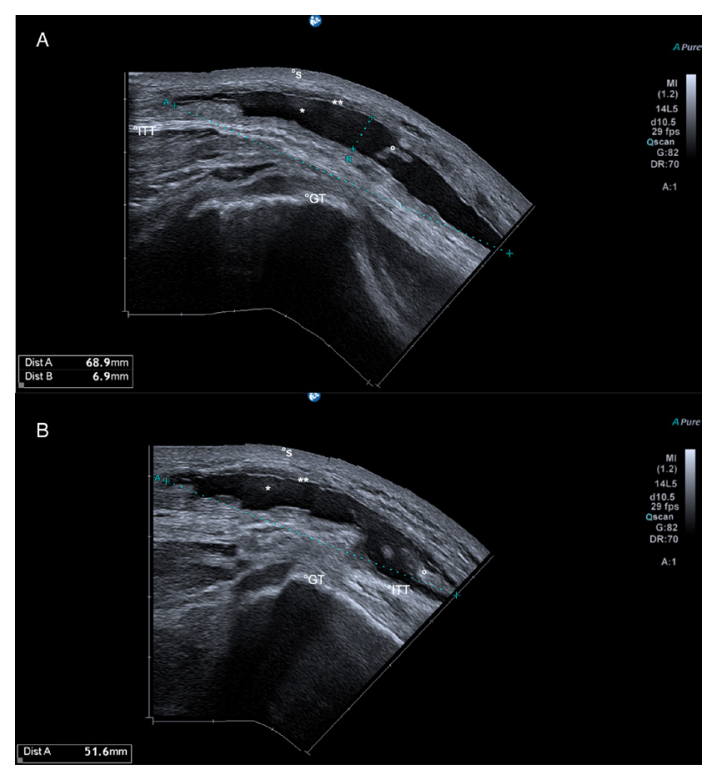

(c) BMJ Publishing Group Limited 2021. No commercial re-use. See rights and permissions. Published by BMJ.

\begin{tabular}{|l|}
\hline To cite: Mutluoglu M, \\
De Melio J, Debrouwere T, \\
et al. BMJ Case Rep \\
2021;14:e243082. \\
doi:10.1136/bcr-2021- \\
243082 \\
\hline
\end{tabular}

Figure 1 Utrasound scan performed using a linear transducer $(12 \mathrm{MHz}$ ) showing long-axis supratrochanteric view $(A)$, and short-axis supratrochanteric view (B). The images demonstrate a homogenous anechoic fluid collection $\left({ }^{*}\right)$, measuring approximately $7 \times 0.7 \times 5 \mathrm{~cm}$ in diameter, associated with scattered hyperechoic substance $\left({ }^{\circ}\right)$ between subcutaneous tissue $\left({ }^{* *}\right)$ and the Ilio-tibial tract (ITT). Annotated additional structures: GT, greater trochanter; S, skin.

\section{Learning points}

- Ultrasoundscan (US) is an efficient tool in the early and accurate diagnosis of suspicious closed wounds.

- Morel-Lavallee lesion is a closed degloving injury that occurs as a result of pressure and shear stress between the subcutaneous tissue and the superficial fascia.

- US is also efficient in the treatment of MorelLavallee lesion as it provides guidance for efficient aspiration of the fluid.

and resulting in a pseudocyst-like fluid collection of blood and/or fat and debris. Depending on the tissue composition, the lesion may also be described as a seroma, haematoma or fat necrosis. ${ }^{1}$ Given this pathogenesis, it is not surprising that the most common site of occurrence is over the greater trochanter as was in our case. ${ }^{2}$ The majority of cases most probably go undetected unless they cause a significant swelling and/or pain.

The lesion itself has no severe implications and can be easily treated unless the diagnosis and treatment are delayed. In this regard, US is an efficient tool in the early and accurate diagnosis of the lesion. ${ }^{3}$ Delayed diagnosis on the other hand may lead to complications such as infection, development of an open wound and may eventually turn into a nonhealing chronic or recalcitrant wound. ${ }^{4}$ Treatment depends on the severity of the condition. While uncomplicated lesions are managed with compression bandaging alone, more severe or delayed cases may require aspiration of the fluid that is best performed using US guidance. ${ }^{5}$ Efficient aspiration usually provides a rapid improvement in symptoms and a complete resolution of the condition. Complicated lesions, however, may require special wound care management and even surgery in several cases. In our specific case, the patient did not require any aspiration and was successfully managed using compression bandaging and a topical anti-inflammatory and antianalgesic gel for 2 weeks with complete relief within 1 month.

Contributors MM designed and wrote the study. JDM and TD participated in reviewing and revising the manuscript. EL reviewed the manuscript for intellectual content.

Funding The authors have not declared a specific grant for this research from any funding agency in the public, commercial or not-for-profit sectors.

Competing interests None declared. 
Images in...

Patient consent for publication Obtained.

Provenance and peer review Not commissioned; externally peer reviewed.

ORCID iD

Mesut Mutluoglu http://orcid.org/0000-0002-1112-5779

\section{REFERENCES}

1 Flato R, Passanante GJ, Skalski MR, et al. The iliotibial tract: imaging, anatomy, injuries, and other pathology. Skeletal Radiol 2017;46:605-22.
2 Khodaee M, Deu RS, Mathern S, et al. Morel-Lavallée lesion in sports. Curr Sports Med Rep 2016;15:417-22.

3 LaTulip S, Rao RR, Sielaff A, et al. Ultrasound utility in the diagnosis of a Morel-Lavallée lesion. Case Rep Emerg Med 2017;2017:3967587.

4 Takahara S, Oe K, Fujita H, et al. Missed massive morel-lavallee lesion. Case Rep Orthop 2014;2014:920317.

5 Walls A, McMahon SE, MacDonald J, et al. Endoscopic surgical management of a large Morel-Lavallée lesion. BMJ Case Rep 2017;2017. doi:10.1136/bcr-2017-221343. [Epub ahead of print: 23 Sep 2017].

Copyright 2021 BMJ Publishing Group. All rights reserved. For permission to reuse any of this content visit https://www.bmj.com/company/products-services/rights-and-licensing/permissions/

BMJ Case Report Fellows may re-use this article for personal use and teaching without any further permission.

Become a Fellow of BMJ Case Reports today and you can:

- Submit as many cases as you like

- Enjoy fast sympathetic peer review and rapid publication of accepted articles

- Access all the published articles

- Re-use any of the published material for personal use and teaching without further permission

Customer Service

If you have any further queries about your subscription, please contact our customer services team on +44 (0) 2071111105 or via email at support@bmj.com.

Visit casereports.bmj.com for more articles like this and to become a Fellow 